\title{
Use of the Core Content Classification in General Practice (3GCP) for qualitative analysis of context and practice. Ten-year study of undergraduate students' final works in the Integrated Master's Degree in Medicine at the University of Coimbra
}

\author{
ARIANA TAVARES ${ }^{1, A, B, D-G}$, LUIZ MIGUEL SANTIAGO ${ }^{1, A, c-G}$, \\ ORCID ID: 0000-0003-3089-8790 ORCID ID: 0000-0002-9343-2827 \\ JOSÉ AUGUSTO SIMÕES ${ }^{3,4, A, D-G}$, INÊS ROSENDO ${ }^{1,4, A, ~ C-G}$ \\ ORCID ID: 0000-0003-2264-7086 ORCID ID: 0000-0001-8838-6021 \\ ${ }^{1}$ Faculty of Medicine, University of Coimbra, Portugal \\ 2 University of Liège, Belgium \\ ${ }^{3}$ Faculty of Health Sciences, University of Beira Interior, Covilhã, Portugal \\ ${ }^{4}$ CINTESIS - Centre for Research in Health Technologies and Service, Porto, Portugal
}

MARC JAMOULLE ${ }^{2, D-F}$

A - Study Design, B - Data Collection, C - Statistical Analysis, D - Data Interpretation, E - Manuscript Preparation, F - Literature Search, G - Funds Collection

Summary Background. General Practice/Family Medicine includes approaches to the biological, technological, behavioural, sociological and anthropological domains.

Objectives. To document the domains addressed in the final assignments of the Integrated Master's Degree in Medicine at the Faculty of Medicine, University of Coimbra, in the area of GP/FM.

Material and methods. Observational study of the titles of final assignments, between 2008 and 2017, granted by the Faculty of Medicine of the University of Coimbra. A domain analysis using as codes the International Classification in Primary Care-2 and the Q-Codes, a context classification in Primary Care, year of elaboration and gender of author was carried out for each title of final assignment. A descriptive and inferential analysis was performed through parametric and nonparametric tests.

Results. 169 papers were analysed, $23.1 \%$ written by male students, with a positive overall growth dynamics $(\Delta=+7)$ between 2008 and 2017. Q-Codes were registered 276 times, while the ICPC-2 codes were used 133 times. Under the Q-Codes, "doctor's issues" is the most frequently addressed $(n=112 ; 67.2 \%)$, and under the International Classification in Primary Care-2 classifications, the chapter "Psychological" was predominant $(n=35 ; 21 \%)$. Under the Q-Codes, subcategories "primary care setting" $(n=26 ; 15.6 \%)$, "health issue management" ( $n=23 ; 13.8 \%)$ and "unable to code, unclear" $(22 ; 13.2 \%)$ were dominant. Within the International Classification in Primary Care-2, the subcategories "diabetes noninsulin dependent" ( $n=22 ; 13.2 \%)$, "depressive disorder" $(8,4.8 \%)$ and "hypertension uncomplicated" $(8 ; 4.8 \%)$ were predominantly focused on.

Conclusions. The 3CGP may become a professional tool, allowing for more precise identification of final works, for a better communication method in medical activity and for avoiding the loss of previously developed works.

Key words: classification, educational measurement, education, medicine, abstracting and indexing as topic.

Tavares A, Santiago LM, Jamoulle M, Simões JA, Rosendo I. Use of the Core Content Classification in General Practice (3GCP) for qualitative analysis of context and practice. Ten-year study of undergraduate students' final works in the Integrated Master's Degree in Medicine at the University of Coimbra. Fam Med Prim Care Rev 2018; 20(4): 363-367, doi: https://doi.org/10.5114/fmpcr.2018.78911.

\section{Background}

General Practice/Family Medicine (GP/FM) is a vast medical area filled with knowledge, and the General Practitioner (GP) is, simultaneously, an incessant user and producer of knowledge. This knowledge is only partly published in medical publications [1]. Studies, abstracts from congresses or dissertations are not available worldwide to professionals, students or researchers due to lack of specific indexation [2].

Many terminologies and classifications supporting existing clinical information and their storage and retrieval have already been drafted [3]. Due to its peculiar dimension, GP/FM includes approaches to the biological, technological, behavioural, sociological and anthropological domains, all of which bear a deep impact on the necessary terminologies [4].

The clinical content of GP/FM is well documented through the International Classification of Primary Care $-2^{\text {nd }}$ edition
(ICPC-2) as a standard method of clinical classification of reasons for consultation, health problems and due procedures $[3,5]$. Even though this classification is close to the taxonomical needs of the GP/FM practice, limitations still exist, namely within the context of practice [6]. Integrating these aspects in the representation of person-centred care [7] and the reflection of due practice by the GP/FM specialist (GPS), according to the European definition of Family Medicine, seems therefore paramount [8].

In 2006, Marc Jamoulle et al. created the terminology to represent the non-clinical or contextual activities of GPs [6]. The author states this contextual addition to the 17 chapters of the ICPC-2 adds accuracy to its domain of applicability [4].

The terminology, named " $Q$ Codes", in its 2.5 version, consists of 182 definitions, divided by 8 domains: person's category, person's issue, doctor's issue, medical ethics, ecological hazard, research and development, structure of practice and knowledge 
management. Each domain is further divided into categories and sub-categories $[3,6]$. This terminology reflects the result of a cooperative two-year project between participants from 12 countries and 8 languages [3]. Thus, the acronym 3CGP (Core Content Classification in Primary Care) is born, as a result of combining the Q-Codes [9] to the ICPC-2 [10].

Each code has a multilingual terminological record, available through the Health Terminology/Ontology Portal (HeTOP) website (https://www.hetop.eu), which is a fundamental resource that mainly includes all terminologies in health. In this web portal, each concept is carefully selected and organised and mapped to Medical Subject Headings (MeSH) with the possibility of subsequent research in the Medline (PubMed) search engine and in the Catalogue et Index des Sites Médicaux de langue Française (CISMef). 3CGP could be searched for in several languages through a dedicated website (http://3cgp.docpatient.net/).

\section{Objectives}

The aim of this paper was to apply the 3CGP to documents the domains of which are addressed in the final assignments of the $6^{\text {th }}$ year of the Integrated Masters in Medicine (IMM) of the FMUC (Faculty of Medicine of the University of Coimbra), carried out within GP/FM, since the beginning of the IMM, in order to evaluate the past and foresee the future. Another objective was to identify differences in themes regarding the gender variable and to understand the usefulness of this resource in structuring and investigating the teaching of medical practice.

\section{Material and methods}

Observational study analysing the IMM final assignments in GP/FM within the FMUC, carried out between 2008 and July 2017.

The information on the FMUC database, with the theme for each IMM final assignment within GP/FM, was provided by this institution, upon approval of both the institution and the Ethics for Health Commission of the Centre Region Regional Health Administration (ARS - Administração Regional de Saúde) on 31 October 2017.

A database was set up (the authors were made anonymous) and organised by title of final assignment, ICPC-2 classification, $\mathrm{Q}$-Codes, year of elaboration and gender of the author. The title was read and coded using the 3CGP: ICPC-2 for clinical aspects and $\mathrm{Q}$-Codes for contextual aspects by reading the abstract, if necessary and when available.

In addition to the 17 chapters of the ICPC-2 [10], the table list of Q-Codes was applied, set up by Marc Jamoulle, available in the "General Practice/Family Medicine Multilingual Terminology" [6] and as an on-line resource [9] (Table 1).

The coding of all papers was carried out by a single author under consultancy with the 3CGP author, Marc Jamoulle.

A descriptive and inferential analysis of the data was performed according to gender, through parametric (Student's T-Test) and nonparametric (Mann-Whitney U Test) tests.
The designation "person" was used to refer to the subject interacting with the physician, as a synonym for patient/consulter/user/client.

\begin{tabular}{|c|c|c|c|c|}
\hline \multirow{2}{*}{$\begin{array}{l}\text { Title of the final } \\
\text { work } \\
\text { The child victim } \\
\text { of physical mal- } \\
\text { treatment } \\
\text { - the interven- } \\
\text { tion of the fam- } \\
\text { ily doctor }\end{array}$} & \multirow{2}{*}{\begin{tabular}{|l|} 
ICPC-2 \\
Z25 \\
assault/ \\
/harmful \\
event
\end{tabular}} & \multicolumn{3}{|l|}{ Q-Codes } \\
\hline & & $\begin{array}{l}\text { QC12 } \\
\text { child }\end{array}$ & $\begin{array}{l}\text { QC52 } \\
\text { child } \\
\text { abuse }\end{array}$ & $\begin{array}{l}\text { QS41 } \\
\text { family } \\
\text { doctor }\end{array}$ \\
\hline $\begin{array}{l}\text { Disease monger- } \\
\text { ing in higher } \\
\text { education: } \\
\text { a study in uni- } \\
\text { versity medical } \\
\text { students }\end{array}$ & - & $\begin{array}{l}\text { QT21 un- } \\
\text { dergradu- } \\
\text { ate }\end{array}$ & $\begin{array}{l}\text { QR323 } \\
\text { cross- } \\
\text { sectional } \\
\text { study }\end{array}$ & $\begin{array}{l}\text { QD442 } \\
\text { disease } \\
\text { monger- } \\
\text { ing }\end{array}$ \\
\hline $\begin{array}{l}\text { Breast cancer } \\
\text { prevention } \\
\text { - knowledge, } \\
\text { attitude and } \\
\text { praxis }\end{array}$ & $\begin{array}{l}\text { X76 ma- } \\
\text { lignant } \\
\text { neoplasm } \\
\text { breast } \\
\text { female }\end{array}$ & $\begin{array}{l}\text { QC22 } \\
\text { women's } \\
\text { health }\end{array}$ & $\begin{array}{l}\text { QD41 } \\
\text { primary } \\
\text { preven- } \\
\text { tion }\end{array}$ & $\begin{array}{l}\text { QP42 } \\
\text { patient } \\
\text { knowl- } \\
\text { edge }\end{array}$ \\
\hline
\end{tabular}

\section{Results}

According to Table 2, 169 papers were analysed, of which $23.1 \%$ were carried out by male students. Positive overall growth dynamics was verified throughout the period under study $(\Delta=+7)$ until the end of 2016 .

The Q-Codes were used 276 times, and the ICPC- 2 codes were used 133 times.

Table 3 includes the classifications by chapters of the ICPC-2, with reference to the 7 most used codes. The codes referring to chapters $\mathrm{H}$ (Ear), $\mathrm{R}$ (Respiratory) and S (Skin) were not mentioned in any of the papers, and the $\mathrm{P}$ (Psychological) chapter was the most frequent. There was a greater frequency of T90 (diabetes noninsulin dependent), P76 (depressive disorder) an K86 (hypertension uncomplicated).

Table 4 includes the distribution of Q-Codes in the 169 IMM final assignments, with reference to the 8 most frequently used subcategories.

Excepting the $\mathrm{QH}$ (planetary health), all other domains were approached, predominantly the QD domain (doctor's issue). Regarding the subcategories, QS1 (primary care setting), QD32 (health issue management) and QO1 (unable to code, unclear) prevail.

According to Table 5, no differences were revealed when analysing the application of the ICPC- 2 and Q-Codes by gender.

Table 2. Number of final assignments of the $6^{\text {th }}$ medical year, distributed by year and gender, and number of Q-codes and ICPC- 2 codes applied

\begin{tabular}{|c|c|c|c|c|c|c|c|c|c|c|c|c|}
\hline Year & & 2008 & 2009 & 2010 & 2011 & 2012 & 2013 & 2014 & 2015 & 2016 & $2017\left(^{*}\right)$ & Total \\
\hline Final pa & & 4 & 12 & 8 & 12 & 13 & 20 & 26 & 23 & 32 & 19 & 169 (100\%) \\
\hline Gender & Male & 1 & 1 & 1 & 3 & 3 & 3 & 7 & 3 & 9 & 8 & 39 (23.1\%) \\
\hline & Female & 3 & 11 & 7 & 9 & 10 & 17 & 19 & 20 & 23 & 10 & 130 (76.9\%) \\
\hline Q-Code & & 10 & 21 & 13 & 17 & 21 & 34 & 41 & 37 & 51 & 31 & 276 \\
\hline ICPC-2C & & 5 & 11 & 11 & 14 & 12 & 16 & 16 & 16 & 20 & 12 & 133 \\
\hline
\end{tabular}

Note $\left(^{*}\right)$ Until July 2017. 


\begin{tabular}{|c|c|c|c|}
\hline Chapter & $n(\%)$ & Code & $n(\%)$ \\
\hline A & $8(4.8)$ & & \\
\hline B & $1(0.6)$ & & \\
\hline D & $3(1.8)$ & & \\
\hline $\mathrm{F}$ & $2(1.2)$ & & \\
\hline $\mathrm{H}$ & 0 & & \\
\hline K & $16(9.6)$ & K86 & $8(4.8)$ \\
\hline L & $3(1.8)$ & & \\
\hline $\mathrm{N}$ & $1(0.6)$ & & \\
\hline $\mathrm{P}$ & 35 (21.0) & \begin{tabular}{|l|} 
P76 \\
P17 \\
\end{tabular} & $\begin{array}{ll}8(4.8) \\
7(4.2) \\
\end{array}$ \\
\hline $\mathrm{R}$ & 0 & & \\
\hline$S$ & 0 & & \\
\hline$T$ & $22(13.2)$ & \begin{tabular}{|l|} 
T90 \\
T82 \\
\end{tabular} & \begin{tabular}{|ll}
14 & $(8.4)$ \\
$4(2.4)$ \\
\end{tabular} \\
\hline U & $2(1.2)$ & & \\
\hline W & $14(8.4)$ & W78 & $5(3.0)$ \\
\hline$x$ & $10(6.0)$ & X75 & $5(3.0)$ \\
\hline$Y$ & $4(2.4)$ & & \\
\hline Z & $5(3.0)$ & & \\
\hline- & $7(4.2)$ & & \\
\hline
\end{tabular}

A - General and unspecified; B - Blood, blood forming organs, lymphatics, spleen; D - Digestive; F- Eye; $\mathrm{H}$ - Ear; $\mathrm{K}$ - Cardiovascular; L - Musculoskeletal; N - Neurological; P - Psychological; R - Respiratory; S - Skin; $T$ - Endocrine, metabolic and nutritional; $U$ - Urology; $W$ - Pregnan$c y$, childbirth, family planning; $X-$ Female genital system and breast; $Y$ - Male genital system; Z - Social problems; - procedures; K86- hypertension uncomplicated; P76 - depressive disorder; P17 - tobacco abuse; T90 - diabetes noninsulin dependent; T82 - obesity; W78 - pregnancy; X75 - malignant neoplasm cervix.

\begin{tabular}{|c|c|c|c|}
\hline Domain & $n(\%)$ & Subcategory & $n(\%)$ \\
\hline \multicolumn{4}{|l|}{ QC } \\
\hline$Q D$ & $112(67.2)$ & $\begin{array}{l}\text { QD32 } \\
\text { QD41 } \\
\text { QD11 } \\
\text { QD42 } \\
\text { QD12 } \\
\end{array}$ & $\begin{array}{l}23(13.8) \\
15(9.0) \\
13(7.8) \\
10(6.0) \\
11(6.6)\end{array}$ \\
\hline $\mathrm{QE}$ & $2(1.2)$ & & \\
\hline $\mathrm{QH}$ & 0 & & \\
\hline QP & $42(25.2)$ & QP42 & $11(6.6)$ \\
\hline QR & $16(9.6)$ & & \\
\hline QS & 39 (23.4) & QS1 & $26(15.6)$ \\
\hline QT & $10(6.0)$ & & \\
\hline QO & $22(13.2)$ & QO1 & $22(13.2)$ \\
\hline
\end{tabular}

QC - person's category; QD - doctor's issue; QE - medical ethics; $\mathrm{QH}$ - planetary health; QP - patient issue; $Q R$ - research; QS - structure of practice; QT - knowledge management; QO - other; QD32 - health issue management; QD41 - primary prevention; QD11 - encounter; QD42 - secondary prevention; QD12 - doctor-person relationship; QP42 - secondary prevention; QS1 - primary care setting; QO1 - unable to code, unclear.

\begin{tabular}{|c|c|c|c|c|c|}
\hline $\begin{array}{l}\text { Number } \\
\text { of codes }\end{array}$ & Gender & $n$ & Average & SD & $p(*)$ \\
\hline \multirow[t]{2}{*}{ ICPC-2 } & Male & 39 & 0.8 & 0.9 & \multirow[t]{2}{*}{0.942} \\
\hline & Female & 130 & 0.8 & 0.7 & \\
\hline \multirow[t]{2}{*}{ Q-Codes } & Male & 39 & 1.5 & 0.6 & \multirow[t]{2}{*}{0.092} \\
\hline & Female & 130 & 1.7 & 0.7 & \\
\hline
\end{tabular}

(*) Student's T-Test.

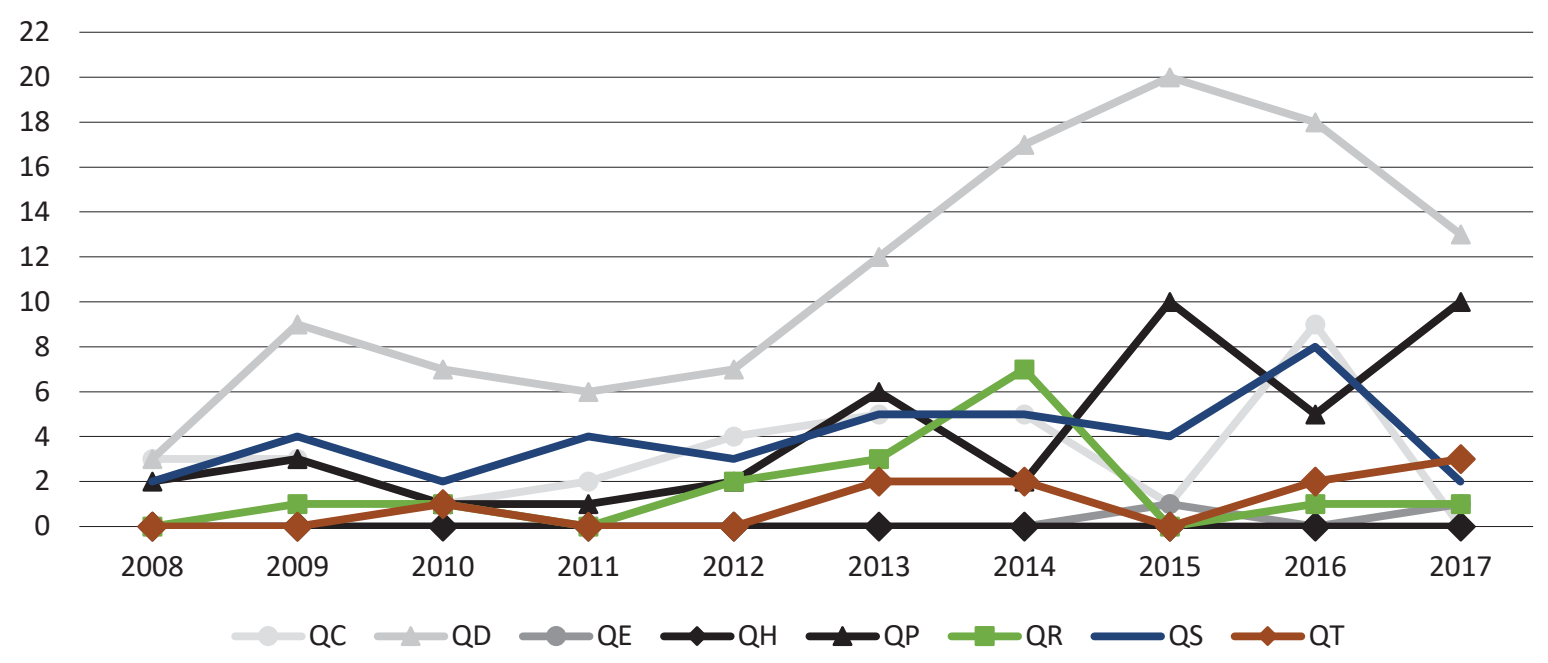

Figure 1. Evolution over time of the contextual contents of the 3CGP in $6^{\text {th }}$ medical year final assignments

QC - person's category; QD - doctor's issue; QE - medical ethics; QH - planetary health; QP - patient issue; QR - research; QS - structure of practice; QT - knowledge management.

Figure 1 shows the evolutionary trend of the 8 domains of $\mathrm{Q}$-Codes, excluding the QO (other) category. During the period under study, the predominance of QD (doctor's issue) is verified. Between 2012 and 2015, a gradual increase in this domain is registered, with a later decline. In 2016, the maximal application of QC (person's category) and QS (structure of practice) domains was registered.

\section{Discussion}

With this study, we are now able to understand what has been chosen by students as the theme of final work and structure of future research, providing visibility to the papers in this area of medicine in this pre-graduated context. 
An article by Salles [11] concerning the role of the doctor within the context of technical and impersonal medicine, oriented towards the market's needs, stimulates the reflection over the study interests of future health professionals. In modern medicine, in which everything is monitored by technology, it is important to understand how future physicians have been adapting to this reality, what they think is important to study and how this evolution has been developing over the last 10 years.

GP/FM has been gradually conquering future physicians, and we have verified a global increase in the number of final assignments in IMM regarding this domain of medicine in the FMUC. However, female students are those who contribute the most to this growth (76.9\%) (Table 1). This tendency can be explained by the greater number of female enrolments (65\%) in relation to male enrolments (35\%) in the FMUC, the overall enrolment being stable since 2007 [12].

When comparing the codification frequency with Q-Codes and the ICPC-2, we verified an overvaluation of Q-Codes. This suggests the importance of non-clinical or contextual aspects in medical assistance, resulting from the will of either the future physicians, their mentors, or both. Hence, the aim was to verify the distribution of ICPC-2 and Q-Codes in detail.

Regarding the ICPC-2 coding, we verified that the $\mathrm{P}$ (Psychological), $T$ (Endocrine, metabolic and nutritional), $\mathrm{K}$ (Cardiovascular) and W (Pregnancy, childbearing, family planning) chapters are the most represented. Analysing the content of communication abstracts in a congress in Portugal, published in 2013 by Jamoulle [1], the P (Psychological), T (Endocrine, metabolic and nutritional), W (Pregnancy, childbearing, family planning) and Z (Social problems) chapters were the most frequently used. This coincidence in thematic areas may indicate that these domains are the most attractive for both future physicians and the young intern physicians in the GP/MF specialty. This pre-eminence of $P \& Z$ domains (psychosocial) is confirmed by content analyse of several congresses in Europe and Brazil [13]. In what extent these results are a function of tutors must be studied. From another perspective, this may be the reflection of a new medicine which, although sophisticated and effective in prolonging life, does not prevent or cure certain diseases. Hence, it is crucial to ponder over the most explored subcategories.

Lobo Antunes states, regarding the modern scientific medicine, that it does not ensure eternity, since "the burden of disease will continue to consist mostly of cardio-cerebral-vascular diseases, lung diseases, diabetes and certain types of cancer" [14]. In contrast with "poverty diseases", these are the "risk diseases" which, incidentally, coincide with those that future physicians analyse the most (Table 3), e.g. Diabetes non-insulin dependent (T90), Hypertension uncomplicated (K86), Depressive disorder (P76) and Malignant cervix neoplasm (X75).

Regarding the application of Q-Codes, QD (doctor's issue) is the most frequently addressed (Table 2 ), and this prevalence was registered throughout the entire period of study (Figure 1). However, a decrease in this domain was registered in 2016 and 2017. In 2016, this decrease coincided with the maximal application of QC (person's category) and QS (structure of practice). Since the real reason for this dynamic is unknown, as a possible hypothesis for justification, we may indicate the curriculum reform in the FMUC from 2015 and the guidance provided by new teachers/tutors, who suggest themes according to their experience, preference or vision for future studies. Since only the papers until June were subject to study in 2017, we cannot fully understand the global number of papers written within that year, in comparison with preceding years, as well as the decrease in papers regarding the $Q D$ domain in that year.
Included in the predominant domain (QD), the QD32 (health issue management) subcategory is the most used. This result may stem from the special training of students who want to work in this area, which favours the person-physician bond, since "it is more important to know the patient affected by the disease than the disease that affects the patient" [14]. It will be all the more interesting to compare the grades with other papers written in other areas within the FMUC.

Scientific and technological progress has determined a transformation in the role of the individual, who is nowadays more aware of his/her rights, more demanding and better informed. Is the current medical teaching in FMUC preparing students for this paradigm shift, providing future physicians with tools to face people with knowledge [15], adapting the best knowledge available to the circumstances, preferences, needs and aims of the individual person, knowing how to lead medical practice to a new culture of protocols, technical procedures, heavy equipment and scientific evidence in an environment of Evidence Based Medicine [16]?

Will the future physician be aware of the concept of quaternary prevention in a critical observation over medical activities, focusing on the need to not harm [17, 18]? This study's results allow us to understand that, regarding quaternary prevention, the statement of lack of knowledge is corroborated until 2017, although prevention is evident in final assignments. The possibility of great belief in EBM and the added pressure of people may justify these results [18-20]. Nevertheless, there is the need to imbed the Research Agenda for General Practice/Family Medicine and Primary Health Care in Europe [21].

As a limitation of this study, we point out the fact that the final assignments were classified almost exclusively by reading the title, which may have been, at times, insufficient, although with consistent help.

We verified that, for some final assignments, the title was not in accordance with the paper itself, and thus we suggest a rigorous definition of the titles in final assignments. We recommend rigorous definition of the titles, which must be precise and relate to the objective and method of the study, writing such assignments in the IMRAD format. In spite of the valued help of the team who created this taxonomy, attention is needed for the possibility of coding errors.

\section{Conclusions}

We verified that contextual aspects are those most frequently addressed in $6^{\text {th }}$ medical year final assignments, in GP/ /MF within the FMUC. In this area, "doctor's issues" are those that carry the most interest for students. In relation to clinical questions, the chapter referring to "psychological" is the one receiving the most attention.

Female students are those who rely the most on GP/FM for their final assignment.

The importance of reflection, by both the educator and the students, is stressed in order to explore areas of high interest that are still under-investigated, i.e. Quaternary prevention, Research Agenda for General Practice/Family Medicine and Primary Health Care in Europe and Person-centred medicine. Future investigations must be structured by creating relevant lines of research that have an impact on the quality of care.

It is important to develop, through this system, an on-line platform to provide information about the domains which have already been researched and to indicate the domains for future research.

Source of funding: This work was funded by the authors' own resources.

Conflicts of interest: The authors declare no conflicts of interest. 


\section{References}

1. Jamoulle M. Using the International Classification for Primary Care (ICPC) and the Core Content Classification for General Practice (3CGP) to classify conference abstracts. Rev Port Med Geral Fam 2013; 29: 334-338.

2. Jamoulle M, Resnick M, Grosjean J, et al. Development, dissemination, and applications of a new terminological resource the Q-Code taxonomy for professional aspects of General Practice/Family Medicine. Eur J Gen Pract 2017; 24(1): 68-73, doi: 10.1080/13814788.2017.1404986.

3. Jamoulle M. Grosjean J, Resnick M, et al. A terminology in General Practice/Family Medicine to represent non-clinical aspects for various usages: the Q-Codes. Stud Health Technol Inform 2017; 235: 471-475, doi: 10.3233/978-1-61499-753-5-471.

4. Jamoulle M. Towards a system of concepts for Family Medicine. Multilingual indexing in General Practice/Family Medicine in the era of Semantic [Doctoral thesis]. Liège: Université de Liège; 2017. Available from URL: http://hdl.handle.net/2268/216132.

5. Pinto D. O que Classificar nos registos clínicos com a Clasificação Internacional de Cuidados Primários. Rev Port Med Geral Fam 2014; 30: 328-334 (in Portugese).

6. Jamoulle M, Treuherz A, Gomes LF, et al. Terminologia Multilíngue de Clínica Geral/Medicina de Família e Comunidade. Jumet: CARE Edition; 2016 (in Portugese).

7. Schrans $D$, Avonts $D$, Christiaens $T$, et al. The search for person-related information in general practice: a qualitative study. Fam Pract 2016; 33: 95-99, doi: 10.1093/fampra/cmv099.

8. World Organization of Family Doctors. The European Definition of General Practice/Family Medicine [serial online] 2011 [cited 16.10.2016]. Available from URL: http://www.woncaeurope.org/sites/default/files/documents/Definition\%203rd\%20ed\%202011\%20 with\%20revised\%20wonca\%20tree.pdf.

9. Rouen University Hospital. HeTOP - Health Terminology/Ontology Portal: The Q-codes [serial online] 2017 [cited 04.11.2017]. Available from URL: http://www.hetop.eu/hetop/Q?la = pt\&rr = CGP_CO_Q\&tab =1\#la = pt\&rr = CGP_CO_Q\&tab = 1\&q = Q.

10. Comité Internacional Classificações WONCA. Classificação Internacional em Cuidados Primários [serial online] 2016 [cited 16.10.2016]. Available from URL: http://3cgp.docpatient.net/wp-content/uploads/2016/12/icpc_copydesk_pt.pdf (in Portugese).

11. Salles AA. Transformações na relação médico-paciente na era da informatização. Rev Bioética 2010; 18: 49-60 (in Portugese).

12. Secretaria-Geral da Educação e Ciência. Dados Estatísticos de Cursos Superiores [serial online] 2017 [cited 04.11.2017]. Available from URL: http://infocursos.mec.pt/dges.asp?code $=0506 \&$ codc $=9813$ (in Portugese).

13. Jamoulle M, Tavares A, Medeiros S, et al. Core Content Classification in General Practice/Family Medicine (3CGP). A new indexing system for General Practice Knowledge management. VDGM PORTO 2018 conference proceedings [serial online] 2018 [cited 16.06.2018]. Available from URL: http://orbi.ulg.ac.be/handle/2268/219300 (in Portugese).

14. Lobo-Antunes J. A Nova Medicina. Porto: Fundação Francisco Manuel dos Santos/Relógio D’Água Editores; 2012 (in Portugese).

15. European Commission DG health and Consumer Protection. Patient safety-making it happen. Luxembourg Declaration on Patient Safety [serial online] 2005 [cited 16.10.2016]. Available from URL: http://ec.europa.eu/health/ph_overview/Documents/ev_20050405_ rd01_en.pdf.

16. Tran THV, Vo TL. Impact of quaternary prevention as a brief intervention in medical students' clinical decisions: experience from Vietnam. Rev Bras Med Fam Comunidade 2015; 10: 1-8, doi: 10.5712/rbmfc10(35)1119.

17. Jamoulle M. Quaternary prevention: first, do not harm. Rev Bras Med Família Comunidade 2015; 10(35): 1-5, doi: 10.5712/rbmfc10(35)1064.

18. Norman AH, Tesser CD. Prevenção quaternária: as bases para sua operacionalização na relação médico-paciente. Rev Bras Med Família Comunidade 2015; 10(35): 1-10, doi: 10.5712/rbmfc10(35)1011 (in Portugese).

19. Normam AH, Tesser CD. Prevenção quaternária na atenção primária à saúde: uma necessidade do Sistema Único de Saúde. Cad Saúde Pública 2009; 25(9): 2012-2020 (in Portugese).

20. Jamoulle M, Gavilán E, Cardoso RV, et al. The words of prevention, part II: ten terms in the realm of quaternary prevention. Rev Bras Med Família Comunidade 2015; 10(35): 1-11, doi: 10.5712/rbmfc10(35)1063 (in Portugese).

21. Royen $\mathrm{PV}$, Beyer $\mathrm{M}$, Chevallier $\mathrm{P}$, et al. Series: The research agenda for general practice/family medicine and primary health care in Europe. Part 3. Results: Person centred care, comprehensive and holistic approach. Eur J Gen Pract 2010; 16(2): 113-119, doi: 10.3109/13814788.2010.481018.

Tables: 5

Figures: 1

References: 21

Received: 20.07.2018

Reviewed: 24.07.2018

Accepted: 01.08.2018.

Address for correspondence:

José Augusto Simões, MD, PhD

Faculty of Health Sciences

University of Beira Interior

Covilhã

Portugal

Tel.: +351924406127

E-mail: jars58@gmail.com 